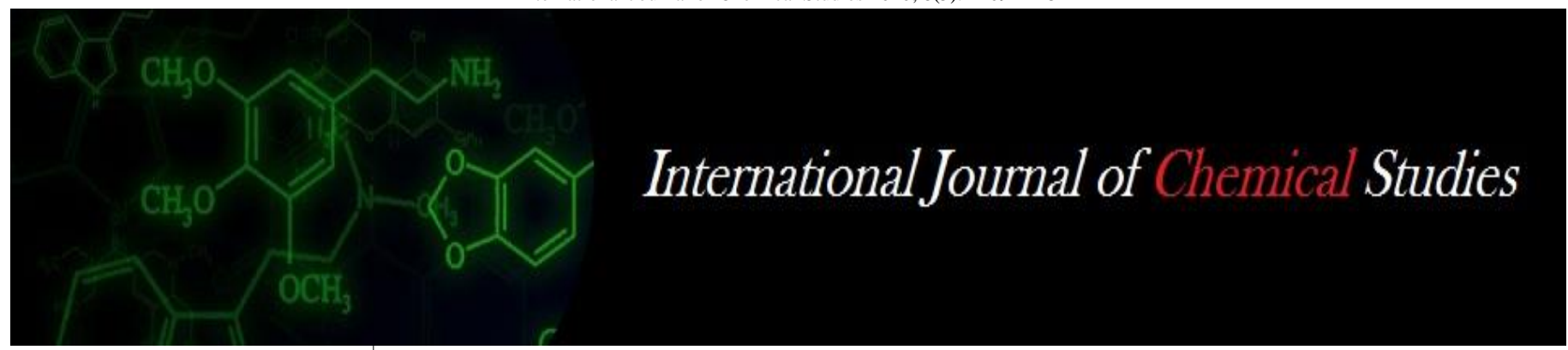

P-ISSN: 2349-8528

E-ISSN: 2321-4902

www.chemijournal.com

IJCS 2020; 8(5): 1109-1115

(C) 2020 IJCS

Received: 12-07-2020

Accepted: 23-08-2020

Shubham Joshi

CSIR-CIMAP, Lucknow,

Uttar Pradesh, India

Suraj Melkani

Govind Ballabh Pant University

of Agriculture and Technology,

Pantnagar, Uttarakhand, India

Monika Yashpal Sajwan

Govind Ballabh Pant University

of Agriculture and Technology,

Pantnagar, Uttarakhand, India

Corresponding Author:

Suraj Melkani

Govind Ballabh Pant University

of Agriculture and Technology,

Pantnagar, Uttarakhand, India

\section{Effect of organic mulching and spacing on soil properties and yield of chamomile (Matricaria chamomilla L.) cv. CIM Sammohak}

\author{
Shubham Joshi, Suraj Melkani, Ardeep and Monika Yashpal Sajwan
}

DOI: https://doi.org/10.22271/chemi.2020.v8.15o.10441

\begin{abstract}
An experiment was conducted during November 2017 to April 2018 at Govind Ballabh Pant University of Agriculture \& Technology, Pantnagar, Uttarakhand, India to study the effect of organic mulching and spacing on soil temperature, soil moisture and yield of chamomile (Matricaria chamomilla L.) cv. CIM Sammohak. The experiment was conducted in split plot design with three replications. There were four level of mulches ( no mulch, rice straw, black gram straw and barnyard millet straw) as main plot treatments and three spacings $(30 \times 10 \mathrm{~cm}, 30 \times 20 \mathrm{~cm}$ and $30 \times 30 \mathrm{~cm})$ as sub-plot treatments. The organic mulch at the rate of 5 ton ha ${ }^{-1}$ was applied in the field after transplanting of chamomile. From the study it was found that barnyard millet straw as mulch had the capacity to conserve the soil moisture and maintain favourable soil temperature for higher plant yield. It was also found out that for higher flower and essential oil yield of chamomile, application of barnyard millet straw at the rate of 5 ton ha ${ }^{-1}$ along with the spacing of $30 \times 10$ can be recommended under tarai conditions.
\end{abstract}

Keywords: Chamomile, Mulch, Spacing, Essential oil, Soil moisture, Soil temperature

\section{Introduction}

Medicinal and aromatic plants have been used in treating human diseases for thousands of years. Conventional medicine is still the chief basis of treating disease for the majority of people in the developing countries. Even among those to whom allopathic medicines are accessible, the numbers of people are using complementary medicines. The basis for the use of these plants is that they contain so-called active ingredients (biologically active principles) that influence physiological or metabolic processes of living organisms, including human beings (Ibrahim, 2012) ${ }^{[3]}$. To meet the augmented demand for quality medicinal and aromatic plant products during the next 25 years, growers and processors will need to focus on various aspects of production, plant preservation, crop domestication, genetic alteration, and product homogeny (Jeliazkova and Craker, 2003) ${ }^{[7]}$. Essential oils of aromatic plants have a market of substantial size which is growing at the rate of 10-15\% every year. The production of essential oil is predictable around Rs. 4,500 cr per year all over the world. India contributes around 10 $\%$ of essential oil production and thus occupies the $3^{\text {rd }}$ place among the developing countries after China (30\%) and Brazil (13\%) (Singh and Kumar, 2000) ${ }^{[14]}$. Chamomile is one of the important aromatic crop which is used extensively in various ayurvedic preparations to boost the immunity.

Botanically chamomile is called Matricaria chamomilla (L.) having $2 \mathrm{n}=18$ and belongs to the family Asteraceae. The oil of chamomile is commonly called 'Blue oil', having medicinal and aromatic significance and is in great demand all over the world. Chamomile plants yield 0.24$1.9 \%$ essential oil. The principal components of the essential oil of chamomile flowers are the terpenoids, $\alpha$-bisabolol and its oxide, azulenes including chamazulene and acetylene derivative. The blue color of the oil is due to sesquiterpene. Other major constituents of the flowers include several phenolic compounds, mainly the flavonoids, apigenin, quercetin, patuletin as glucosides and various acetylated derivatives (Singh et al. 2011) ${ }^{[15]}$.

Among various factors accountable for optimum vegetative growth and higher flower production, suitable mulches and plant densities have been proved useful under various agroclimatic conditions. For the profitable production of many crops, the use of mulch has become 
a significant cultural practice to get better plant growth. Mulches can effectively diminish water vapour loss, soil erosion, weed problems and nutrient loss (Van Derwerken and Wilcox-Lee, 1988) ${ }^{[19]}$. When mulch is positioned over the soil surface, an optimistic soil-water-plant relation is formed (Clough et al., 1990) ${ }^{[4]}$. The use of straw as mulch provides a more attractive option for farmers. The key factors that make straw mulch attractive is low cost (US \$ $9.6 \mathrm{ha}^{-1}$ as against US \$ $94.5 \mathrm{ha}^{-1}$ for polythene mulch and US \$ $25 \mathrm{ha}^{-1}$ for chemical mulch) and ease in availability and application. Organic mulches may also prove better in the long run as they improve soil organic matter and are environment-friendly.

Flower and oil yield of chamomile can be maximized by adjusting the seedling population to counterpart the moisture conditions of the environment, that is, densely populated plants utilize moisture and nutrients more quickly than meagerly populated plants (Tadess and Chala, 2017) ${ }^{[17]}$. Plant population is the most significant yield contributing character which can be manipulated to conquer the maximum production from a unit land area. Plants have significant capability to develop an environment with changeable competition stresses under diverse plant population. Enlarged plant density, even though reduces the yield of individual plants, but increases the yield per unit area. Plant densities have an imperative role in the physiological implementation of the plant. The planting distance manipulates the availability of nutrients, water, and light to plant which have an effect on the photosynthetic activities which have an eventual effect on plant growth and yield. A crop of much significance, Chamomile still lacks status and preference under field condition.

\section{Materials and Methods \\ Experimental Site}

The present field experiment was conducted during 2018-19 at the Medicinal Plant Research and Development Centre, G.B. Pant university of Agriculture and Technology, Pantnagar, U.S. Nagar (Uttarakhand). The experimental site has geographical location of $29^{\circ} \mathrm{N}$ latitude, $79.3^{\circ} \mathrm{E}$ longitude .It is at an altitude of 243.84 meters above mean sea level.

\section{Soil Characteristics}

The soils of tarai region in Pantnagar are developed from alluvial material, medium to moderately coarse in texture. The soils are developed from mollic epipedons with weakly developed horizons. These soils are classified as mollisols. The experimental soil was rich in soil organic matter, neutral in soil reaction, low in soil available nitrogen, medium in soil available phosphorus and medium in soil available potassium

\section{Experimental Details}

The present study was conducted in split plot design with three replications. There were four level of mulches as main plot treatments ( no mulch, rice straw, black gram straw and barnyard millet straw) and three spacings $(30 \times 10 \mathrm{~cm}, 30 \times 20$ $\mathrm{cm}$ and $30 \times 30 \mathrm{~cm}$ ) as sub-plot treatments. The organic mulching rate of application was 5 ton $\mathrm{ha}^{-1}$ which was applied in the field after transplanting. A common dose of 10 tonne FYM was also applied in each plot.

\section{Observations recorded}

Different plant and soil parameters were recorded during the study. Plant parameters, number of flowers per plant, dry flower yield per hectare, essential oil yield per hectare and soil parameters, soil surface temperature and soil moisture were analyzed.

\section{Statistical Analysis}

The statistical analysis was carried out on computer using the split plot design STPR package. Wherever the effects exhibited significance at 5 per cent level of probability, the critical difference (CD) was calculated at $5 \%$ level of significance.

\section{Results and Discussion \\ Number of flowers per plant}

Numbers of flowers per plant were counted at the time of peak flowering stage. The data pertaining to the effect of organic mulch and plant spacing on number of flowers per plant is presented in table 1.1.

The data from the above table clearly shows that at the time of peak flowering, maximum numbers of flowers per plant (566.41) were recorded under Barnyard millet straw mulch, which was significantly superior over all other main plot treatments.

Spacing also showed significant effect on number of flowers per plant at the time of peak flowering. The number of flowers, recorded at $30 \times 30 \mathrm{~cm}$ plant spacing (551.22) was also significantly higher as compare to other two plant spacing.

Interaction results at different levels of mulching and spacing also showed significant effect on number of flowers per plant, the related data presented in table 1.2 and in fig. 1 . The plants grown at $30 \times 30 \mathrm{~cm}$ plant spacing bore significantly more number of flowers per plant under different mulch treatments as compared to other plant spacings. The successive significant increase was found in number of flowers per plant with each increase in plant spacing $(30 \times 10 \mathrm{~cm}$ to $30 \times 30 \mathrm{~cm})$. The significantly higher number of flowers per plant was recorded in Barnyard millet straw treatment irrespective of plant spacing.

The mulches provided congenial environment for plant growth and development as evident by the lesser soil surface temperature and higher moisture content. The barnyard millet straw could have decomposed faster as compared to other mulches, which led to release of nutrients for plant growth and development and in turn more flower production. Patel, B.B. (2013) ${ }^{[11]}$ also found the similar results in tuberose with paddy straw. At wider spacing, there is less competition for available resources and the plant have a chance to develop more number of branches and leaf that could be the reason for a maximum number of fresh flowers per plant obtained in wider spacing than in closer spacing. Similar result was also found by Tadesse N. and Chala M. (2017) ${ }^{[17]}$ in chamomile.

Table 1: Effect of organic mulch and spacing on number of flowers per plant

\begin{tabular}{|c|c|}
\hline Treatments & Number of flowers per plant \\
\hline \multicolumn{2}{|c|}{ Mulch Treatments } \\
\hline No Mulch & 475.05 \\
\hline Rice Straw & 522.53 \\
\hline Black gram Straw & 501.92 \\
\hline Barnyard Millet Straw & 566.41 \\
\hline
\end{tabular}




\begin{tabular}{|c|c|}
\hline SEm \pm & 3.33 \\
\hline CD $(5 \%)$ & 11.74 \\
\hline $30 \times 30 \mathrm{~cm}$ & 551.22 \\
\hline $30 \times 20 \mathrm{~cm}$ & 530.01 \\
\hline $30 \times 10 \mathrm{~cm}$ & 468.19 \\
\hline SEm \pm & 3.63 \\
\hline CD $(5 \%)$ & 10.97 \\
\hline
\end{tabular}

Table 2: Interaction effect of mulch and spacing on number of flowers per plant

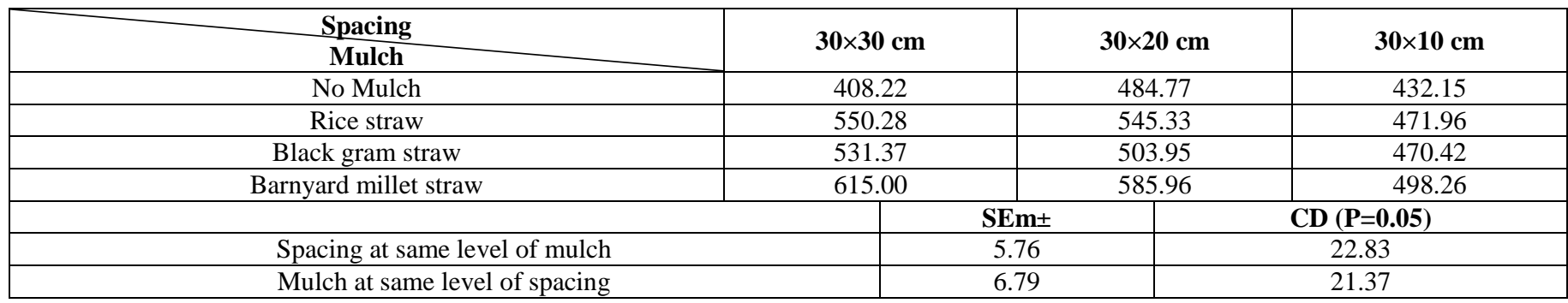

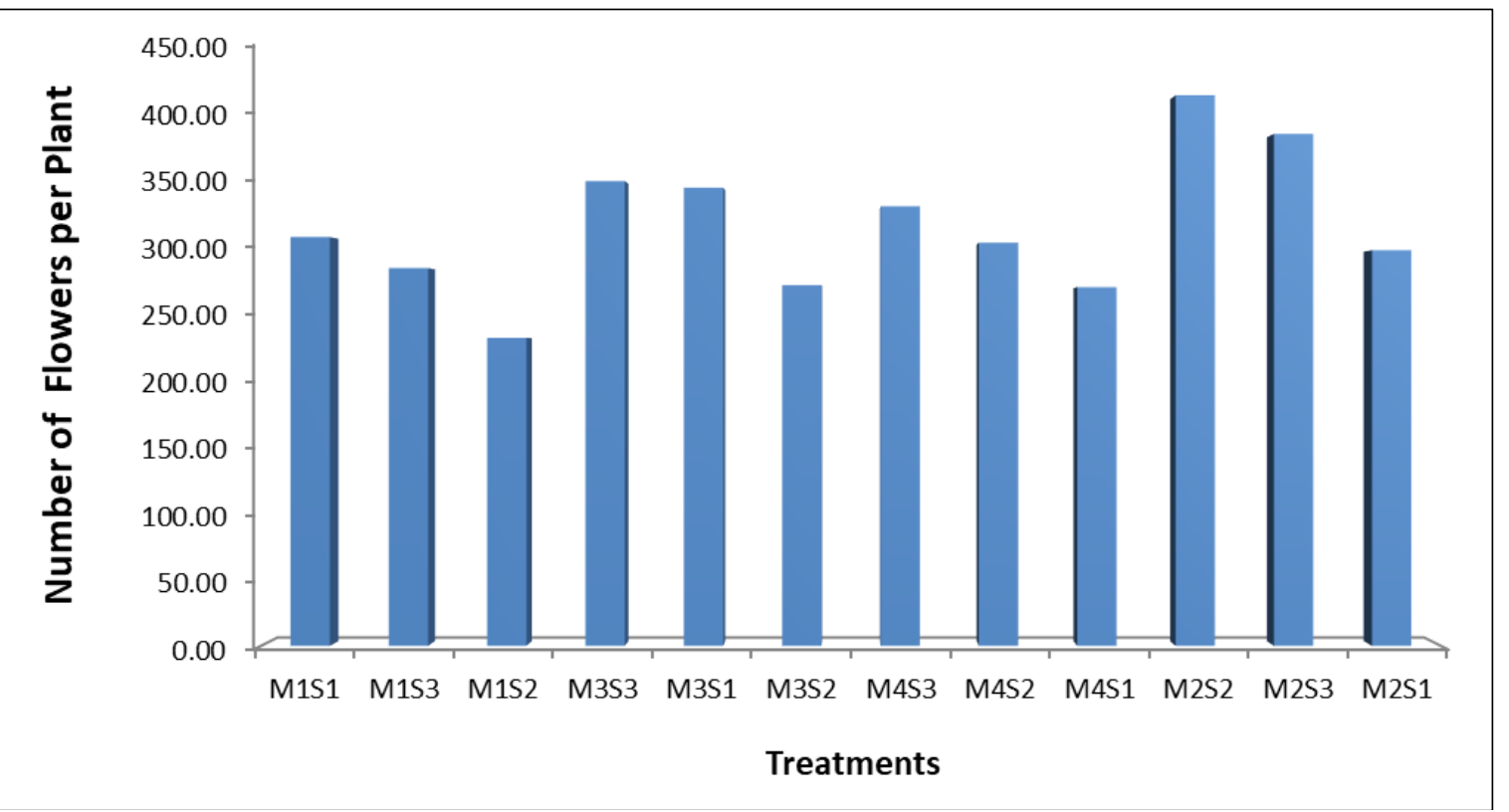

Fig 1: Effect of Mulching and Spacing on Number of Flowers per Plant

\section{Dry flower yield per hectare}

Dry flower yield was calculated at the time of peak flowering. The data pertaining to the effect of organic mulch and plant spacing on dry flower yield is presented in table 2.1.

Maximum dry flower yield was obtained under barnyard millet straw (961.66 kg/ha), which was on a par with rice straw and significantly higher than black gram straw and no mulch treatment.

Spacing also showed significant effect on dry flower yield. Dry flower yield recorded at $30 \times 10 \mathrm{~cm}$ plant spacing was significantly higher $(1,265.83 \mathrm{~kg} / \mathrm{ha})$ as compare to other two plant spacing.

Interaction results at different levels of mulching and spacing also showed significant effect on dry flower yield, the related data presented in table 2.2 and in fig. 2. In case of dry flower yield, at $30 \times 30 \mathrm{~cm}$ plant spacing the maximum dry flower yield was observed under barnyard millet straw (722.22 $\mathrm{kg} / \mathrm{ha}$ ). At $30 \times 20 \mathrm{~cm}$ plant spacing the maximum flower yield was observed under barnyard millet straw $(915.00 \mathrm{~kg} / \mathrm{ha})$, which was significantly higher than all other mulch treatment. At $30 \times 10 \mathrm{~cm}$ plant spacing maximum flower yield was recorded under rice straw $(1,304.44 \mathrm{~kg} / \mathrm{ha})$, which was significantly higher than all other mulch treatment. Flower yield at no mulch treatment with $30 \times 10 \mathrm{~cm}$ plant spacing were found to be maximum $(1,255.56 \mathrm{~kg} / \mathrm{ha})$, which was significantly superior over all other plant spacing. Flower yield at rice straw treatment with $30 \times 10 \mathrm{~cm}$ plant spacing was found to be maximum $(1,304.44 \mathrm{~kg} / \mathrm{ha})$, which was significantly superior over all other plant spacing. Flower yield under black gram straw treatment with $30 \times 10 \mathrm{~cm}$ plant spacing was found to be maximum $(1,255.56 \mathrm{~kg} / \mathrm{ha})$, which was significantly superior over all other plant spacing. Flower yield at barnyard millet straw mulch treatment with $30 \times 10 \mathrm{~cm}$ plant spacing was found to be maximum $(1,247.77 \mathrm{~kg} / \mathrm{ha})$, which was significantly superior over all other plant spacing. The mulches provided affable environment for plant growth and development as marked by the lesser soil surface temperature and higher moisture content. The barnyard millet straw could have decomposed faster as compared to other mulches, which led to release of nutrients for plant growth and development and in turn increases dry flower yield. Houman, H. (2010) ${ }^{[6]}$ found the similar results in chamomile. Dry flower weight also at the narrow spacing was higher due to a high number of plants per unit area. Similar results were obtained by Hadi et al. $2004^{[5]}$ in chamomile. 
Table 3: Effect of organic mulch and spacing on dry flower yield (kg/ha)

\begin{tabular}{|c|c|}
\hline Treatments & Dry Flower yield (kg/ha) \\
\hline \multicolumn{2}{|c|}{ Mulch Treatments } \\
\hline No Mulch & 913.76 \\
\hline Rice Straw & 952.09 \\
\hline Black gram Straw & 944.38 \\
\hline Barnyard Millet Straw & 961.66 \\
\hline SEm \pm & 3.92 \\
\hline CD $(5 \%)$ & 13.80 \\
\hline \multicolumn{2}{|c|}{ Spacing } \\
\hline $30 \times 30 \mathrm{~cm}$ & 687.96 \\
\hline $30 \times 20 \mathrm{~cm}$ & 875.14 \\
\hline & $1,265.83$ \\
\hline
\end{tabular}

\begin{tabular}{|c|c|}
\hline SEm \pm & 3.52 \\
\hline $\mathrm{CD}(5 \%)$ & 10.64 \\
\hline
\end{tabular}

Table 4: Interaction effect of mulch and spacing on dry flower yield per hectare $(\mathrm{kg} / \mathrm{ha})$

\begin{tabular}{|c|c|c|c|}
\hline $\begin{array}{c}\text { Spacing } \\
\text { Mulch }\end{array}$ & $\mathbf{3 0 \times 3 0} \mathbf{~ c m}$ & $\mathbf{3 0 \times \mathbf { 2 0 }} \mathbf{~ c m}$ & $\mathbf{3 0 \times \mathbf { 1 0 }} \mathbf{~ c m}$ \\
\hline No Mulch & 640.74 & 845.00 & $1,255.56$ \\
\hline Rice straw & 696.29 & 885.56 & $1,304.44$ \\
\hline Black gram straw & 692.59 & 885.00 & $1,255.56$ \\
\hline Barnyard millet straw & 722.22 & 915.00 & $1,247.77$ \\
\hline \multicolumn{5}{|c|}{ SEm \pm} & $\mathbf{C D}(\mathbf{P}=\mathbf{0 . 0 5})$ \\
\hline Spacing at same level of mulch & 6.77 & 22.41 \\
\hline Mulch at same level of spacing & 6.95 & 22.13 \\
\hline
\end{tabular}

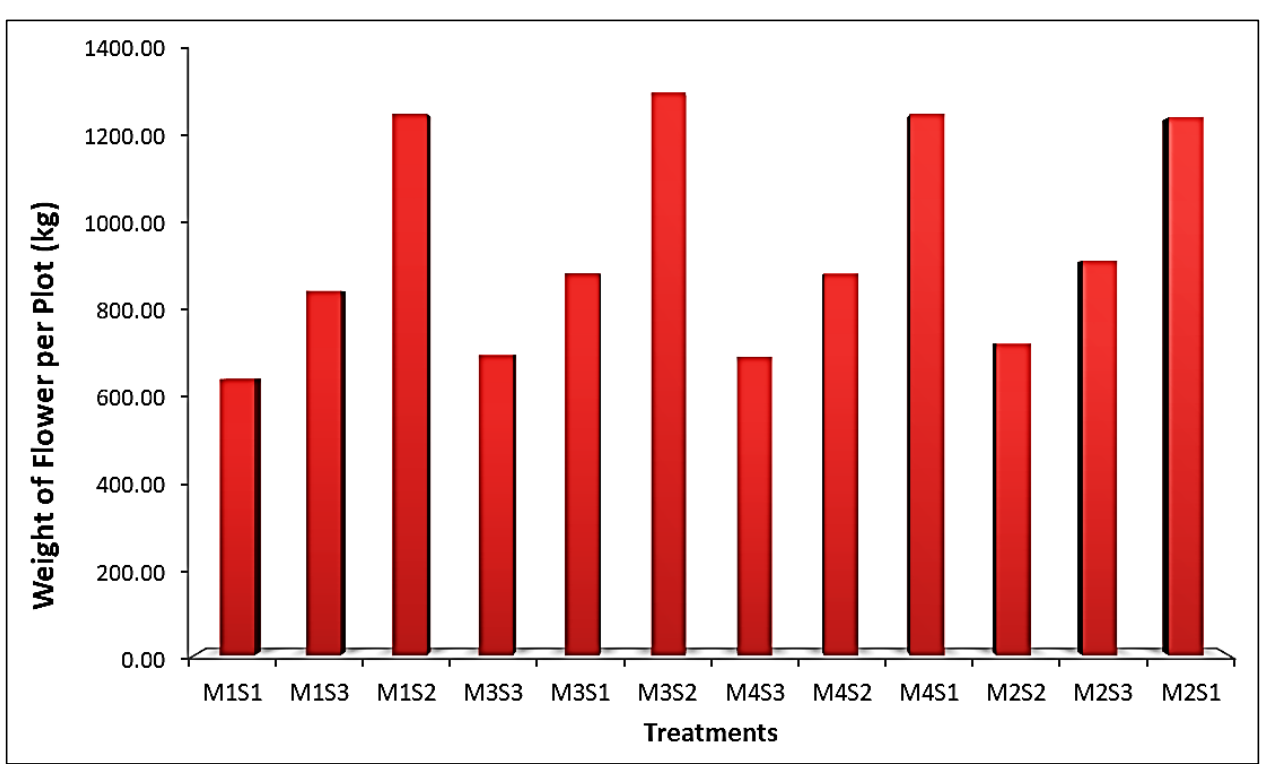

Fig 2: Flower yield per hectare

\section{Essential oil yield}

Essential oil yield was calculated after essential oil extraction. Data due to the effect of organic mulching and spacing on essential oil yield is presented in table 3.1.

Mulch shows the significant effect on essential oil yield. Maximum oil was present under barnyard millet straw (4.66 $\mathrm{kg} / \mathrm{ha}$ ). Amount of essential oil recorded at $30 \times 10 \mathrm{~cm}$ plant spacing was significantly higher $(6.22 \mathrm{~kg} / \mathrm{ha})$ as compare to other two plant spacing.

Interaction results at different levels of mulching and spacing also shows significant effect on essential oil yield, which are shown in table 3.2 and fig. 3 . At $30 \times 30 \mathrm{~cm}$ plant spacing the maximum essential oil was observed under black gram straw $(2.88 \mathrm{~kg} / \mathrm{ha})$, which was not significantly higher than all other mulch treatment. At $30 \times 20 \mathrm{~cm}$ plant spacing the maximum essential oil was recorded under barnyard millet straw (4.39 $\mathrm{kg} / \mathrm{ha}$ ), which was significantly higher than all other treatments. At $30 \times 10 \mathrm{~cm}$ plant spacing maximum essential oil was recorded under barnyard millet straw $(6.74 \mathrm{~kg} / \mathrm{ha})$. Essential oil under no mulch was not significantly higher than black gram straw treatment. All the mulch treatments and no mulch treatment exhibited significant superiority at $30 \times 10 \mathrm{~cm}$ plant spacing followed by $30 \times 20 \mathrm{~cm}$ plant spacing for essential oil yield.

Muni Ram et al. (2003) [13] also found that rice straw increased essential oil yield $(\mathrm{kg} / \mathrm{ha})$ in geranium over no mulch. Yadav et al. (1994) ${ }^{[19]}$ in sugarcane found the similar results. Tadesse N. and Chala M. (2017) ${ }^{[17]}$ also found that in chamomile, maximum essential oil yield obtained under shorter spacing. The result indicated that the closer spacing accommodates more plant number per unit area than wider spacing that may contribute to more number and weight of flower led to significantly higher essential oil yield.

Table 5: Effect of organic mulch and spacing on essential oil yield (kg/ha)

\begin{tabular}{|c|c|}
\hline Treatments & Essential oil yield (kg/ha) \\
\hline \multicolumn{2}{|c|}{ Mulch Treatments } \\
\hline No Mulch & 4.08 \\
\hline Rice Straw & 4.44 \\
\hline Black gram Straw & 4.13 \\
\hline Barnyard Millet Straw & 4.66 \\
\hline SEm \pm & 0.08 \\
\hline CD $(5 \%)$ & 0.30 \\
\hline \multicolumn{2}{|c|}{ Spacing } \\
\hline $30 \times 30 \mathrm{~cm}$ & 2.77 \\
\hline $30 \times 20 \mathrm{~cm}$ & 4.01 \\
\hline SEm \pm & 6.22 \\
\hline CD $(5 \%)$ & 0.09 \\
\hline
\end{tabular}




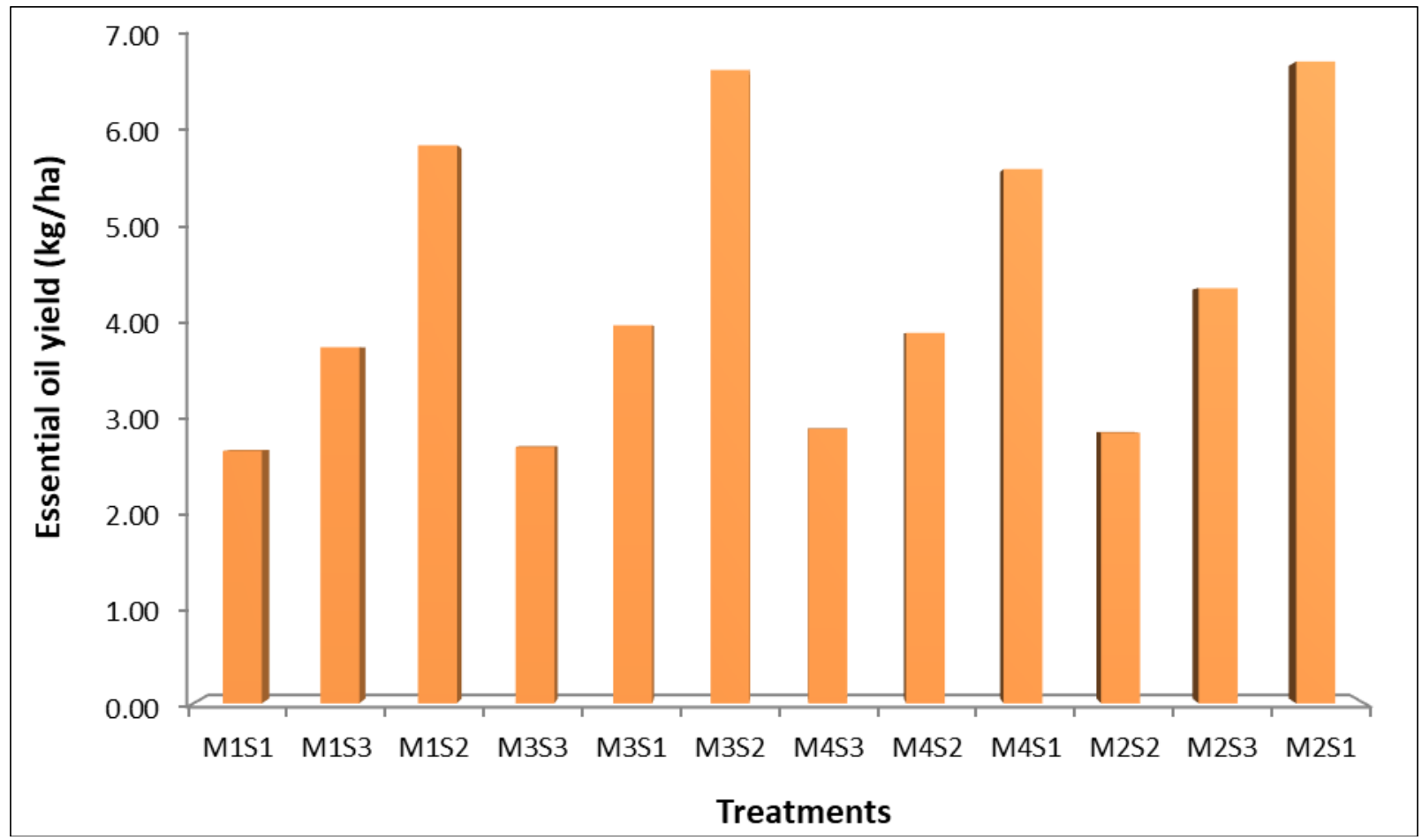

Fig 3: Essential oil yield

Table 6: Interaction effect of mulch and spacing on essential oil yield $(\mathrm{kg} / \mathrm{ha})$

\begin{tabular}{|c|c|c|c|c|c|}
\hline $\begin{array}{c}\text { Spacing } \\
\text { Mulch }\end{array}$ & \multicolumn{2}{|c|}{$30 \times 30 \mathrm{~cm}$} & \multicolumn{2}{|c|}{$30 \times 20 \mathrm{~cm}$} & $30 \times 10 \mathrm{~cm}$ \\
\hline No Mulch & \multicolumn{2}{|c|}{2.65} & \multicolumn{2}{|c|}{3.74} & 5.86 \\
\hline Rice straw & \multicolumn{2}{|c|}{$\frac{2.05}{2.69}$} & \multicolumn{2}{|c|}{3.97} & 6.65 \\
\hline Black gram straw & \multicolumn{2}{|c|}{2.88} & \multicolumn{2}{|c|}{3.89} & 5.61 \\
\hline Barnyard millet straw & \multicolumn{2}{|c|}{2.84} & \multicolumn{2}{|c|}{4.39} & 6.74 \\
\hline & & \multicolumn{2}{|c|}{ SEm \pm} & \multicolumn{2}{|c|}{$\mathrm{CD}(\mathrm{P}=\mathbf{0 . 0 5})$} \\
\hline \multicolumn{2}{|c|}{ Spacing at same level of mulch } & \multicolumn{2}{|c|}{0.07} & \multicolumn{2}{|r|}{0.33} \\
\hline \multicolumn{2}{|c|}{ Mulch at same level of spacing } & \multicolumn{2}{|c|}{0.09} & \multicolumn{2}{|r|}{0.29} \\
\hline
\end{tabular}

\section{Soil surface temperature}

Soil surface temperature was taken at 15, 30 and 45 days after mulching (DAM) and at the time of peak flowering. Data pertaining to the effect of organic mulching and spacing on soil surface temperature is presented in table 4.1

The effect of mulches on soil surface temperature remained statistically similar at all the crop growth stages except at peak flowering stage, at which no mulch and black gram straw mulch's effect remained on a par. However, under no mulch treatment, soil surface temperature remained maximum and significantly higher at all the crop growth stages over other mulch treatments. The effect of spacing could not influence soil surface temperature significantly at all the crop growth stages except at 45 DAM. At 45 DAM, the soil surface temperature remained maximum and significantly higher as compared to all other spacing levels.

Table 7: Effect of organic mulch and spacing on soil surface temperature $\left({ }^{\circ} \mathrm{C}\right)$ at various stages of crop growth

\begin{tabular}{|c|c|c|c|c|}
\hline \multirow{2}{*}{ Treatments } & \multicolumn{4}{|c|}{ Soil surface temperature $\left({ }^{\circ} \mathrm{C}\right)$} \\
\hline & 15 DAM & 30 DAM & 45 DAM & Peak flowering \\
\hline \multicolumn{5}{|c|}{ Mulch Treatments } \\
\hline No Mulch & 18.62 & 16.69 & 18.18 & 21.99 \\
\hline Rice Straw & 13.48 & 13.55 & 16.38 & 20.29 \\
\hline Black gram Straw & 13.95 & 14.01 & 17.27 & 21.17 \\
\hline Barnyard Millet Straw & 13.07 & 12.76 & 16.38 & 20.24 \\
\hline SEm \pm & 0.17 & 0.29 & 0.22 & 0.35 \\
\hline $\mathrm{CD}(5 \%)$ & 0.59 & 1.05 & 0.76 & 1.22 \\
\hline \multicolumn{5}{|c|}{ Spacing } \\
\hline $30 \times 30 \mathrm{~cm}$ & 14.64 & 14.60 & 17.48 & 21.10 \\
\hline $30 \times 20 \mathrm{~cm}$ & 14.78 & 14.24 & 17.01 & 20.99 \\
\hline $30 \times 10 \mathrm{~cm}$ & 14.92 & 13.92 & 16.67 & 20.68 \\
\hline SEm \pm & 0.16 & 0.20 & 0.13 & 0.23 \\
\hline $\mathrm{CD}(5 \%)$ & NS & NS & 0.376 & NS \\
\hline
\end{tabular}

Similar results have also been reported by Amini and AlamiMilani (2013) ${ }^{[1]}$. They observed that in the control treatments soil surface temperature was maximum as compare to straw mulch. The mulch prevents evaporation of water from the soil surface. At the same time, water moves from deeper soil layers to the topsoil by capillarity and vapor transfer, thereby keeping the topsoil water content relatively stable. Straw mulching is regarded as one of the best ways of improving water retention in the soil and reducing soil evaporation (Baumhardt and Jones, 2002; Zhang et al., 2009) ${ }^{[2,20]}$. Kumar et al. (2014) [8] also found that from May to June, soil temperature was lower in poplar and silver oak tree leaf mulch (organic mulch) compared to pine needle and unmulched control. 


\section{Soil moisture}

Soil moisture was taken at 15, 30 and 45 days after mulching (DAM) and at the time of peak flowering at the depth of 15 $\mathrm{cm}$. Data pertaining to the effect of organic mulching and spacing on soil moisture is presented in table 5.1.

Soil moisture varied with different mulch treatments at different days intervals. Moisture decreased from the date of mulching to peak flowering. At 15 DAM, maximum soil moisture was recorded under rice straw (17.37\%). At 30 DAM maximum soil moisture was recorded under black gram straw (15.94\%), which was significantly superior over all other mulch treatments and no mulch treatment. At 45 DAM maximum soil moisture was recorded under rice straw $(9.12 \%)$.At peak flowering stage, the soil moisture content differed significantly in all the mulch treatments, being maximum under barnyard millet straw treatment $(9.78 \%)$.

The effect of plant spacing on soil moisture content was found to be significant only at 30 DAM and at peak flowering. Soil moisture at 30 DAM was found to be maximum at $30 \times 30 \mathrm{~cm}$ plant spacing $(13.76 \%)$. Soil moisture at the time of peak flowering was found to be maximum at $30 \times 10 \mathrm{~cm}$ plant spacing $(8.68 \%)$, which was significantly superior over all other plant spacing.

Table 8: Effect of organic mulch and spacing on soil moisture (\%) at various stages of crop growth

\begin{tabular}{|c|c|c|c|c|}
\hline \multirow{2}{*}{ Treatments } & \multicolumn{5}{|c|}{ Soil moisture (\%) } \\
\cline { 2 - 5 } & 15 DAM 30 DAM & 45 DAM & Peak flowering \\
\hline \multicolumn{5}{|c|}{ Mulch Treatments } \\
\hline No Mulch & 16.08 & 12.17 & 3.69 & 5.4 \\
\hline Rice Straw & 17.37 & 13.22 & 9.12 & 8.6 \\
\hline Black gram Straw & 16.03 & 15.94 & 7.77 & 7.47 \\
\hline Barnyard Millet Straw & 16.89 & 12.79 & 7.56 & 9.78 \\
\hline SEm \pm & $\mathbf{0 . 1 7}$ & $\mathbf{0 . 1 3}$ & $\mathbf{0 . 1 1}$ & $\mathbf{0 . 0 3}$ \\
\hline CD (5\%) & $\mathbf{0 . 6 2}$ & $\mathbf{0 . 4 5}$ & $\mathbf{0 . 3 6}$ & $\mathbf{0 . 1 2}$ \\
\hline \multicolumn{5}{|c|}{ Spacing } \\
\hline $30 \times 30$ cm & 16.63 & 13.76 & 7.72 & 7.67 \\
\hline $30 \times 20 \mathrm{~cm}$ & 16.55 & 13.71 & 6.79 & 7.07 \\
\hline $30 \times 10 \mathrm{~cm}$ & 16.59 & 13.11 & 7.13 & 8.68 \\
\hline SEm \pm & $\mathbf{0 . 1 9}$ & $\mathbf{0 . 1 7}$ & $\mathbf{0 . 1 8}$ & $\mathbf{0 . 0 5}$ \\
\hline CD $(5 \%)$ & NS & $\mathbf{0 . 5 2}$ & NS & $\mathbf{0 . 1 4}$ \\
\hline
\end{tabular}

Similar results were also found by Sinkeviciene et al. (2009) [16], who found that the highest soil moisture content was in plots mulched with peat and with sawdust compared with soil moisture in plots without mulch. Rahman et al. (2005) [12] found that soil moisture at the surface layer $(0-15 \mathrm{~cm})$ decreased faster in the plots with no straw mulch. Manakul (1994) ${ }^{[9]}$ also reported that soil moisture content under rice straw mulch was higher than that of bare soil.

Based on the present experiment investigation we can conclude that rice straw and barnyard millet straw showed significant effect on different plant and soil parameters. $30 \times 30 \mathrm{~cm}$ plant spacing showed significant effect on numbers of flowers per plant, fresh and dry weight of flower per plant, soil surface temperature and soil moisture. $30 \times 10 \mathrm{~cm}$ plant spacing showed significant effect on fresh flower yield, dry flower yield, essential oil content and essential oil yield. Furthermore, the result of interaction showed that rice straw with $30 \times 10 \mathrm{~cm}$ spacing recorded maximum dry flower production and barnyard millet straw with $30 \times 10 \mathrm{~cm}$ plant spacing recorded highest essential oil production. Mulch also increased the soil moisture, decreased soil surface temperature and suppressed weeds for better growth of the crop.

\section{References}

1. Amini R, Alami-Milani M. Effect of mulching on soil, canopy and leaf temperature of lentil (Lens culinaris Medick). International Journal of Farming and Applied Sciences. 2013; 2(20):797-802.

2. Baumhardt RL, Jones OR. Residue management and tillage effects on soil-water storage and grain yield of dry land wheat and sorghum for a clay loam in Texas. Soil and tillage research. 2002; 68(2):71-82.

3. Ibrahim A, Gilerson A, Harmel T, Tonizzo A, Chowdhary J, Ahmed S. The relationship between upwelling underwater polarization and attenuation/absorption ratio. Opt. Express. 2012; 23:25662-25680.

4. Clough GH, Locascio SJ, Olson SM. Yield of successively cropped polyethylene mulched vegetables as affected by irrigation methods and fertilization management. J Amer Soc Horti Sci. 1990; 115:884-87.

5. Hadi MHS, Noormohammadi G, Sinaki JM, Khodabandeh N, Yasa N, Darzi MT. Effects of planting time and plant density on flower yield and active substance of Chamomile (Matricaria chamomilla L.). In Fourth International Crop Science Congress, Brisbane, Australia, 2004.

6. Houman H. Effect of water stress and mulching on morphological and biochamical characteristics of Matricaria chamomilla L. (Doctoral dissertation, University of Agricultural Sciences GKVK, Bangalore), 2010.

7. Jeliazkova EA, Craker LE. Seed germination of some medicinal and aromatic plants in heavy metal environment. Journal of Herbs, Spices \& Medicinal Plants. 2003; 10(2):105-112.

8. Kumar R, Sood S, Sharma S, Kasana RC, Pathania VL, Singh B, Singh RD. Effect of plant spacing and organic mulch on growth, yield and quality of natural sweetener plant Stevia and soil fertility in western Himalayas. International Journal of Plant Production. 2014; 8(3):311-334.

9. Manakul T. Response of wheat to straw mulching (Doctoral dissertation, MS Thesis in Agriculture (Agriculture System).Graduate School of Chiang Mai University, Chiang Mai, Thailand), 1994.

10. Mashingaidze AB. Improving weed management and crop productivity in maize systems in Zimbabwe. $\mathrm{Ph}$. D. Thesis, Wageningen University, the Netherlands, 2004, 196.

11. Patel BB. Effect of irrigation levels and mulching on growth and yield of Tuberose (Polianthestuberosa L.) var."Prajwal (Doctoral dissertation, Navsari Agricultural University, Navsari), 2013.

12. Rahman MA, Chikushi J, Saifizzaman M, Lauren JG. Rice straw mulching and nitrogen response of no-till wheat following rice in Bangladesh. Field Crops Research. 2005; 91(1):71-81.

13. Ram M, Ram D, Roy SK. Influence of an organic mulching on fertilizer nitrogen use efficiency and herb and essential oil yields in geranium (Pelargonium graveolens). Bioresource technology. 2003; 87(3):273278.

14. Singh RP, Kumar RK. Ecological approaches in weed management. In extended summaries (Voluntary articles), golden jubilee national symposium on "Conservation agriculture and environment" at the BHU, Varanasi, India on, 2000, 26-28. 
15. Singh O, Khanam Z, Misra N, Srivastava MK. Chamomile (Matricaria chamomilla L.). An overview Pharmacognosy Rev. 2011; 5(9):82-95.

16. Sinkeviciene A, Jodaugiene D, Pupaliene R, Urbonien M. The influence of organic mulches on soil properties and crop yield. Agronomy Research. 2009; 7(1):485-491.

17. Tadesse N, Chala M. Influence of Plant Population Density on Growth and Yield of Chamomile (Matricaria chamomilla L.) at Wondo Genet, South Ethiopia. Advances in Crop Science and Technology. 2017; 5:318.

18. Van Derwerken JE, Wilcox-Lee D. Influence of plastic mulch and type and frequency of irrigation on growth and yield of bell pepper. Hortscience. 1988; 23(6):985-988,

19. Yadav RL, Prasad SR, Singh R, Srivastava VK. Recycling sugarcane trash to conserve soil organic carbon for sustaining yields of successive ratoon crops in sugarcane. Bioresource technology.1994; 49(3):231-235.

20. Zhang S, Lovdahl L, Grip H, Tong Y, Yang X, Wang Q. Effects of mulching and catch cropping on soil temperature, soil moisture and wheat yield on the Loess Plateau of China. Soil and Tillage Research. 2009; 102(1):78-86. 